establishment of an administrative examination of appropriate standard for passing from the general grade of clerical officers to the higher grades.

OTHER recommendations relato to the adoption of uniform grading systems and salary scales, the wide notification of vacancies, the establishment of a minimum age limit of sixteen years, couplod with the possession of a school certificate for entry to the service. A certain proportion of junior clerical officers should be recruited at eighteen or nineteen years of age, apart from the systematic recruitment of university graduates and of professional and tochnical officers from all available sources. A thorough investigation of technical qualifications is required, and coupled with greater precautions against personal influence in making appointments, greater mobility of officers between local authorities, tho assignment by each local authority to one establishment com. mittee of all questions sffecting the recruitment, qualification, training and promotion of officers; these suggestions should assist in the devolopment of a local government service able to meet the increasingly onerous demands made upon it.

\section{New Cheshire Nature Reserves}

The two Nature reserves in memory of the late T. A. Coward, the well-known naturalist and author of "The Birds of Cheshire" and "The Vertebrate Fauna of Cheshire", of tho Manchester Museum, who died on January 29, 1933, have been completed in Cheshire. They have been formed by a committee of naturalists and admirers, the T. A. Coward Memorial Fund, under the chairmanship of the Right Hon. the Earl of Stamford; though as yot some $£ 200$ of the purchase money is required. It is proposed to hand the reserves over to the care of somo national body like the National Trust. The two sites chosen were Marbury Mere in mid-Cheshire, and Cotterrill's Clough, a 'hanying' wood on the banks of the River Bollin within sight of (Coward's home at Bowdon (Nature, 132, 437, Sept. 16, 1933). Fach locality is rich in bird life. At the latter, Coward recorded the grasshopper-warbler, and used it for the recording of the arrival of migrant species, whilo the former, which includes a large lake and $1 \frac{1}{8}$ acres of woodland, and large reed beds which bring the extent up to 8 acres, is where the black tern, bittern, night-heron, whooper swan, Bowick's swan, and groat crested grebe have been recorded. Somo recent Marbury records include the white wagtail, a drake and two duck wigeon in July, scaup duck, goosander, cormorant, great northern diver, and ringed plover (Nineteenth Annual Report, Lancushire and Cheshiro Jauna (committee). The honorary secretary of the Coward Memorial Fund is Mr. J. F. Hodkinson, 50 Selby Street, Manchester, 11.

\section{Roman Scotland}

Sir George Macdonald's reconstruction of the history of the Roman wall from Forth to Clyde, and of the strategic position in Roman Scotland in the second century A.D. from the evidence of his excavations, which appeared in the Times of April 7, justifies his citation of the dictum of the late Prof. Haverfield that the spade would prove mightier than the pen, but at the same time will suggest to his readers the qualification that its superiority depends upon the skill of the excavator, and his constructive powers in the interpretation of his finds. Sir George's ability in this respect enables him to piece together the data he has obtained from the thirty-seven miles of wall between Bridgeness on the Forth to Old Kilpatrick on tho Clyde, with its forts, ditch and flanking road for supply purposes, and to supply from it a conclusive solution for the more puzzling problems of a political and military situation which required the building of the forward lino of defence and yet at the same time did not relieve the garrison of Hadrian's wall to the south. The key to the situation, which he now supplies, is the vulnerability of the intra-mural area from the inroads of the Dalriada Scots of Ireland through Galloway. Further, he suggests, the country north of York, being occupied in a military sense only, even though the outer wall provided an officient barrier against attack by the northern tribes, it was necessary to have a garrison on the southern wall to shut off the partially subdued tribes. on the southern side of the wall from those in the occupied Scottish area, in order to prevent any junction of disaffected tribesmen. Sir George's suggestion that shortage of man power and a miscalculation of the pressure which could be brought to bear by Irish inroads is a logical, but none the less brilliant, reading of the situation when about 185 A.D. the outer lino of defence was abandoned.

\section{An Expedition to Hainan}

Although the flowering plants of Hainan have been extensively collected by Prof. Woon-Young Chun and his associates of the Botanical Institute, National Sun-Yatsen University, Canton, the animals of the island, although previously collected by a few naturalists, are still incornpletely known to the scientific world. The Fan Momorial Institute of Biology, the Biological Laboratory of the Science Society of China, the Metropolitan Musoum of Natural History of the Academia Sinica, the National Tsing Hua University, the National University of Peking, the National Shantung University and Nankai University have recently organisod a joint expedition to Hainan. The purpose of this is to collect zoological specimens as extensively as possible. Cryptogams, orchids and wood samples will also be collected. The Fan Memorial Institute of Biology will be represented by C. Ho, entomologist, and S. K. Tang, taxidermist; the Biological Laboratory of the Science Society of China by Dr. C. C. Wang, inverte. brate zoologist, and Mr. K. F. Wang, ichthyologist; the Metropolitan Museum of Natural History by Dr. H. W. Wu, ichthyologist; the National Shantung University by Mr. C. L. Tso, botanist, and Mr. Chungsi H. Liu, anthropologist; and Nankai University by Dr. T. S. Hsiung, invertebrate zoologist. Mr. C. L. Tso, who has had previous experience in the island and is familiar with the natives, will lead the expedition. The members of the expedition were to leave Shanghai about January 15. One party 